\title{
South Africa's Short and Long Term Interest Rates: A Threshold Cointegration Analysis
}

\author{
Smile Dube \\ Department of Economics, California State University Sacramento \\ 6000 J Street, Sacramento, California 95819-6082 \\ Tel: 916-278-7518Ｅ-mail: dubes@csus.edu \\ Yan Zhou (Corresponding Author) \\ Department of Economics, California State University Sacramento \\ 6000 J Street, Sacramento, California 95819-6082 \\ Tel: 916-278-7653Ｅ-mail: yzhou@csus.edu
}

Received: January 14, 2013 Accepted: February 19, 2013

doi:10.5296/ber.v3i1.3121 URL: http://dx.doi.org/10.5296/ber.v3i1.3121

\begin{abstract}
This paper presents a two-regime vector error-correction model (VECM) with a single cointegrating vector and a threshold effect in the error-correction term. We use a Hansen-Seo (2002) algorithm to extract maximum likelihood estimates in eight threshold cointegration model s that relate short-term to long-term interest rates in South Africa for the period 1990M1-2010M7. We employ a SupLM test to test for the presence of threshold. The Hansen-Seo algorithm yields both linear and non-linear estimates plus critical values used to test threshold effects. The method is applied by relating the South Africa Reserve Bank policy rate, the repo (short-term) to intermediate (TB rate, money market rate) and long-term rates (the 10-year government bond, the loan and deposit rates). In all cases, linear cointegration is rejected in favor of a threshold effect.
\end{abstract}

Keywords: Market interest rates, Threshold cointegration, SARB, Repo (repurchase rate) JEL Classification: C32 


\section{Introduction}

There is a generally acceptance that monetary policy actions influence economic activity with a time lag that ranges from 4 months to 2 years (Romer and Romer, 1989). There are six identifiable channels of monetary policy transmission: (1) the interest rate channel, (2) the bank lending channel, (3) the balance sheet channel, (4) the asset price channel, (5) the exchange rate channel, and (6) the expectation channel. Of these, the interest channel is often viewed as more important since all other channels are related to changes in it (Isakova, 2008).

The South African Reserve Bank (SARB) relies on the idea that changes in the policy rate (the repo) prompt similar changes in short-money market instruments and retail rates (loan and deposit). Under perfect information with no uncertainty, adjustments costs, and perfect competition, market interest rates including the government yields, the responses to policy rate change should be immediate, symmetric and one-for-one. The objective of this paper is to establish whether this assertion holds when the SARB changes the repo rate as part of its monetary policy. We do so by relating the repo rate to eight interest rates using monthly data for the $1990 \mathrm{M} 1-2010 \mathrm{M} 7$. $^{\mathrm{i}}$

The motivation for examining the term structure of interest rates is fourfold. The focus on trying to understand bond yield movements is important for South Africa for at least four reasons outlined in Piazzesi (2010). The first is that the yield curve is associated with monetary policy. Although it is now clear that the central bank (SARB) can change the repo rate, this means that the bank can move the short end of the yield curve. However, it is long-term yields that matter for aggregate demand. For example, South African households base their decision whether to buy a house or rent depends on long-term mortgage rates represented in this paper by loan rates (LR), participation bond rates (MLR_Bond), and the bank rate on housing bonds (MLR_Bank) and not on the repo rate that is controlled by the South Africa Reserve Bank (SARB). ${ }^{\text {ii }}$ For a given state of the economy (business cycle), a model of the yield curve helps participants including policy makers to understand how movements at the short end translate into longer-term yields. An understanding of how the central bank conducts its monetary policy and how the monetary transmission mechanism works with expectations hypothesis is the main building block in such models.

Second, there is need for forecasting where yields on longer maturity bonds are stated to be the expected value of average future short yields after one adjusts for risk. The yield spreads are useful for forecasting future short yields (Campbell and Shiller, 1991;Cochrane and Piazzesi, 2005), for real economic activity (Ang et al., 2006), and for inflation (Mishkin, 1990 and Hamilton and Kim, 2002) even if forecasted relationships tend to be unstable (Stock and Watson, 2003 and Piazzesi , 2010). Third, bond yields are important in the area of debt management. In issuing new government debt, the issuing agency has to decide on the maturity of bonds. The standard example is from Piazzesi (2010). The Kennedy administration managed the maturity of public debt via 'operation twist.' The government was interested in flattening or inverting the yield curve by selling short maturity debt and buying long maturity notes. Fourth, bond yields are critical in derivative pricing and hedging. ${ }^{\text {iii }}$ Coupon bonds are priced as baskets of coupon payments weighted by the price of a zero-coupon bond that matures on the coupon 
date. Commercial banks also need to manage the risk of paying short-term interest rates (the deposit rate, DR in this paper) while receiving long-term interest rates on loans (loan rate, LR in the paper).

\section{Post-Card Review of South Africa's Interest Rates}

Government bonds are fixed-interest bearing securities that are government-issued whose rate of return is measured by the government bond yield. South African government bonds are a negotiable and transferable instrument listed on the Bond Exchange of South Africa, and can be issued for various terms up to 25 years. The South African Reserve Bank (SARB) acts as an agent of the government in placing new bonds on auction through a system of primary dealers. These bonds are issued over a long period and hence the yields represent a measure of long-term interest rates. Treasury bills are short-term obligations of the government or debt obligations which are bearer form with a term not exceeding 12 months. Tender bills with a maturity of 91 days, 182 days, and 273 days are allocated by the SARB on behalf of the government at a weekly tender on Fridays for settlement the following week. The weekly Treasury-bill tender rate is a prime indicator of money-market conditions.

The repurchase rate (repo rate) is the interest at which commercial banks (such ABSA, Standard Bank, FNB, and Nedbank) borrow from SARB. ${ }^{\text {iv }}$ To make profit banks lend money to bank customers at a higher prime rate. Thus, the repo rate, a short-term money market rate, is a crucial determinant of commercial bank funding costs. Thus, sustained movements in the repo will always end up in a compensating move in bank's prime lending and deposit rates. Each day, the SARB makes available a certain amount of funding to commercial banks through repo transactions which involves banks selling securities to the SARB in return for funds. The funds are made available against the obligation to purchase back the securities at an agreed price at a future date. Since the repo rate is variable, the banks essentially determine the rate at which they submit bids since the final repo rate is the average of the rates attached to all successful bids. ${ }^{\mathrm{v}}$ In order to avoid borrowing at the punitive rate, banks often increase the rate at which they bid for repo funds, pushing the repo rate upwards.

The repo rate is one factor that controls the money supply which in turn impacts national debt levels, business growth, inflation, and consumer spending. An increase in the repo rate indicates that the SARB has tightened monetary policy basically for two reasons. First, with tight monetary policy, the repo rate increases, followed by increases in all interest rates. The critical issue is not whether other rates do follow but whether other interest rates (MMR, DR, LR, TB, MLR_Bank, and MLR_Bond) follow in a one-to-one or less than one-to-one adjustments (see Figure 1). The aim of a repo hike by the SARB is to control inflation to within the official 3\%-6\% target band. ${ }^{\mathrm{vi}}$ The second reason for hiking the repo rate is to fend of speculators against the domestic currency. That is, higher interest rates accomplish two things: encourage capital inflows (foreign direct investment and portfolio inflows) that are necessary to cover current account deficits, and the strengthening of the Rand (ZAR) when speculators expect a depreciating currency.

Earlier in 1998, the SARB had temporarily suspended the variable repo rate in favor of a fixed repo so that by June 1998, the spread between the fixed repo rate and the marginal lending rate 
was 15 percentage points. By June 1998, it was clear that the Rand would remain under attack by speculators. The SARB widened the spread between the marginal lending rate and the repo rate to 20 percentage points. As a result, the average repo increased to 20.38 , which was 3.38 percentage points above the fixed repo of the previous and the marginal lending rate was adjusted to 40.38 per cent. Money market rates (such as 3-month Banker's Acceptance) increased from 14.95 per cent in May to 19.00 per cent by the end of June. The 3-month rate increase cascaded through other money market rates. The effect of changes in the interbank rate increased bank's overall funding costs (deposit rates) and lending rates as well. Although changes in the repo are passed-through (not one-to-one) to changes in money market rates (3-month TB rate, MMR), they are lead to increases in lending and deposit rates. ${ }^{\text {vii }}$ Figure 1 shows the behavior of all interest rates, including an upward shift in all interest rates in June 1998.

\section{Yields on Long-term and Short-Term Bonds}

The yield curve shows the trend of interest rates of different maturities. The yield curve plots yields or interest rates on bonds with different terms of maturity but the same risks, liquidity and tax arrangements (Mishkin, 2004). The yield on government bonds of different maturity, $\mathrm{TB}$, mortgages, lending and deposit rates can be used to represent the yield curve. In case of South Africa, Nel (1996) and Khomo and Aziakpono(2007) used the yields on 10-year bond (long-term) and 3-month Treasury bill (short-term) to derive the yield spread. Bonga-Bonga (2008) employed a structural vector autoregressive model (SVAR) to characterize the dynamic responses of the short and long-term rates to supply, demand and monetary policy shocks in South Africa. Moolman (2002), Ballim and Moolman(2005), and Aron and Muellbauer (2006) use the forward rate agreements ${ }^{\text {viii }}$ as proxies for interest rate expectations to establish whether market participants can correctly predict the SARB decision on the repo rate before each MPC meeting (there are 6 meetings per year). He found that the movement in market interest rates occurs in anticipation of policy action, rather than one the day the repo rate is changed. Arize et al. (2002) examined the long-run relationship between short-term (represented by either TB rates or call money or money market) and long-term interest rates (represented by government bond yield) in nineteen countries including South Africa for the 1973-1998 period. They found support for the expectations hypothesis in all countries except in the U.K.

The interest in examining the yields of different maturities is related to the important issue -monetary policy transmission. The change in monetary policy stance is transmitted to achieve a stable and low inflation with economic growth. The key channel through which monetary policy changes (for example, changing the repo rate) are transmitted to the economy is via effects on market interest rates. Monetary policy is deemed successful if repo changes affect a whole spectrum of interest as seen in Figure 1. Taylor (1995) points to the difficulty in assessing the relevance of short-term and long-term interest rates on economic activity (consumption and investment demands). Simply put, which interest rate should policy changes pursue in order to stimulate economic growth and hence solve unemployment rates? 


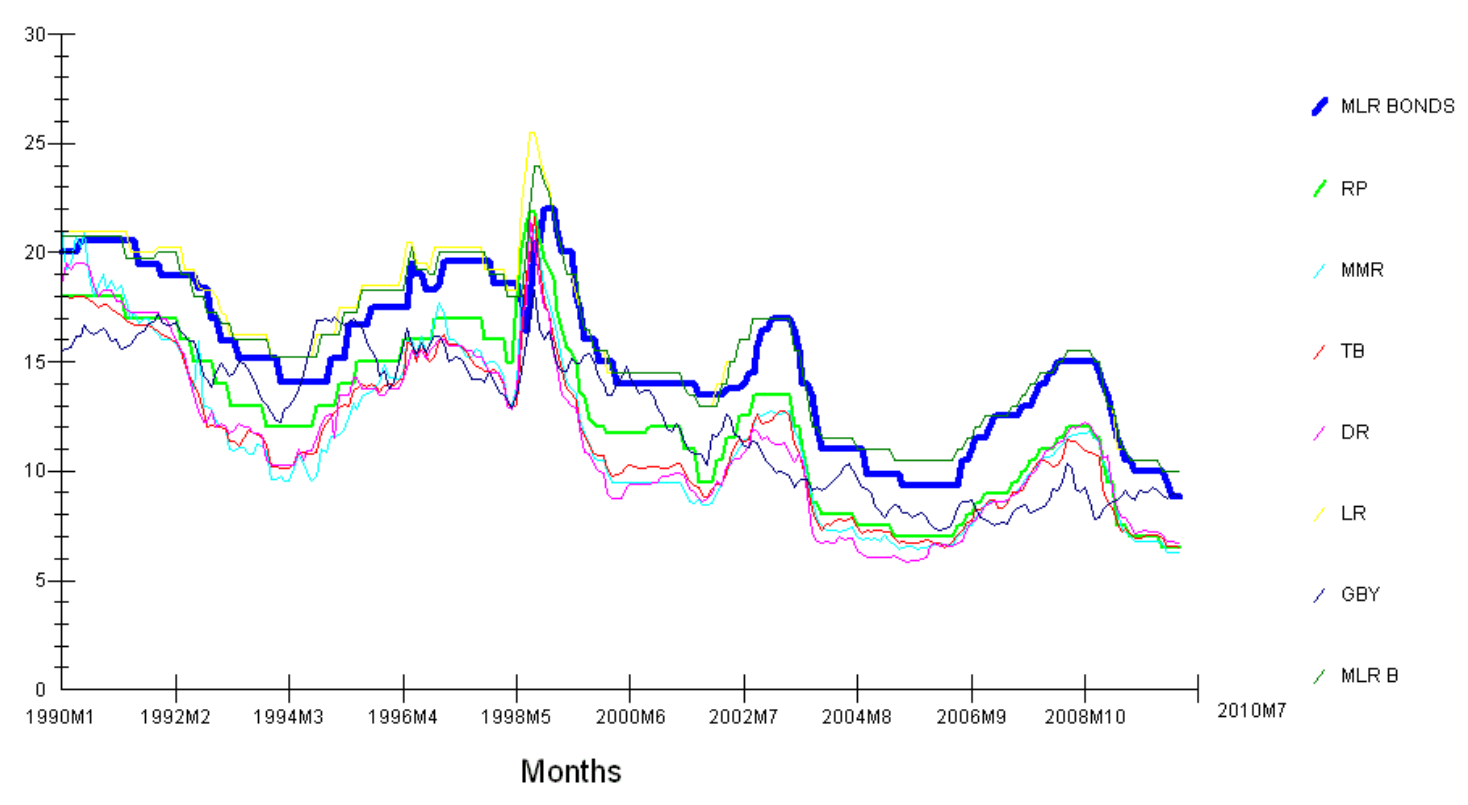

Figure 1. The Repo Rate and its Relationship to Money Market Rates, and Yields

There are studies that point to monetary policy as having predictable effects on short-term interest rates. For the 1973-2004 period, Aziakpono et al. (2007) point to the high response of overnight prime interbank and 3-month negotiable certificate of deposit to changes in the repo rate in South Africa. For the U.S., Roley and Sellon (1995) show that short-term rates mimic the federal funds rate. For the U.K., Dale (1993) showed that policy actions by the Bank of England have significant effects of interest rates of all maturities although the effects tend to decay as maturities become longer. In Germany, Hardy (1998) found that market rates react to changes in the official rate depends on the extent to which the change is anticipated and on how it is interpreted as a signal for future policy. During the 1990s, Kaketsis and Sarantis (2006) studied the transmission process between the Bank of Greece's policy instruments and market rates at different maturities. They found that an increase in anticipations of market interest forces to policy changes. The effect of policy rate changes tended to decline with the lengthening of maturities.

For the 1970s, Cook and Hahn (1989) examined the effect of changes in the federal funds rate on market rates in the U.S. for various maturities on the day or around the day of changes in the federal funds rate. They found that changes in the federal funds rate caused large movements in short-term rates but smaller and yet significant movements in intermediate and long-term rates (Bonga-Bonga, 2008). Thornton (1998) also examined the response of market interest rates to changes in the federal funds rate on the day the policy rate is announced. He found out the responds of the 10-year and 30-year Treasury rates was statistically insignificant.

Figure 1 illustrates the monthly relationship between long-term rates and short-term rates over the 1990-2010 period. The loan rate (LR), the marginal lending rate of banks/mortgage rate (MLR_B), and the participation rate/mortgage rate (MLR_Bonds), and the government bond yield (GBY) are long-term rates that are higher than short-term rates (TB, MMR). This behavior characterizes a normal yield curve. However, Figure 1 shows cases of an inverted 


\section{Macrothink}

Business and Economic Research ISSN 2162-4860 2013, Vol. 3, No. 1

yield curve prior to economic downturns. Incidentally, an inverted yield curve gives support to the expectations hypothesis. According to Mishkin (2004), if the SARB tightens monetary policy by raising the repo during a recession, most market participants will view such a policy change as a temporary shock and hence they will expect future short-term rates (forward rates) to increase by less than one-to-one (incomplete interest rate pass-through), leading to a fall in long-term interest rates. However, during the upswing in the business cycle, a repo increase will result in expected future short-term rates rising by more that the repo change (over 100\% pass-through), so that long-term interest rates increase by more than short-term rates.

\section{Threshold Cointegration, Data, Model and Estimation}

Following Balke and Fomby (1997), Hansen and Seo (2002), and Ahmad and Pentecost (2005), the threshold vector of two endogenous variables are long-term interest rates $\left(R_{t}\right)$ and short-term interest rates $\left(r_{t}\right)$ are given as:

$$
x_{t}=\left(R_{t}, r_{t}\right)^{\prime}
$$

which is a 2 dimensional I(1) series with variables as defined above. The model assumes that series $r_{t}$ and $R_{t}$ have a long-run relationship with a cointegrating scalar of $\beta$ that is to be estimated. A linear vector error correction model (VECM) of order $l+1$ is presented as

$$
\Delta x_{t}=A^{\prime} X_{t-1}+u_{t}
$$

where $\Delta$ is the first order difference operator, the regressor is $X_{t-1}$ is a kx1 matrix, $\Delta$ is $\mathrm{kx} 2$, $k=2 l+4$. The error term, $u_{t}$ is assumed to be $2 \times 1$ and with a finite covariance matrix $\sum=E\left(u_{t}, u_{t}{ }^{\prime}\right)$. If there is a threshold, then the coefficient matrix $\Delta$ determines the dynamics in each of the regimes assuming the cointegrating vector is a scalar. From (2), $X_{t-1}$ can be written as

$$
X_{t-1}=\left(\begin{array}{l}
1 \\
w_{t-1} \\
\Delta x_{t-1} \\
\Delta x_{t-2} \\
\vdots \\
\Delta x_{t-l}
\end{array}\right)
$$

If the long-term interest rate is nonstationary, that is, I(1), then (1) represents a system that is 
cointegrated with the error-correction term, ${ }_{t-1}=R_{t-1}-\beta r_{t-1}$. If $\beta=1$, then the error-correction term, $w_{t-1}$, is just the interest rate spread. Both ADF and PP unit root tests in Table 2 indicate that the short-term and long-term rates are I(1) for all interest rates. The Hansen and Seo (2002) paper on term structure of interest rates discusses imposing $\beta=1$ and estimating the threshold parameter only. However, they do not report these results.ix Again based on Hansen and Seo (2002) and Ahmad and Pentecost (2005), (2) could be written as:

$$
\Delta x_{t}=\left\{\begin{array}{lll}
A_{1}{ }^{\prime} X_{t-1}(\beta)+u_{t} & \text { if } & w_{t-1}(\beta) \leq \gamma \\
A_{2}{ }^{\prime} X_{t-1}(\beta)+u_{t} & \text { if } & w_{t-1}(\beta) \succ \gamma
\end{array}\right\}
$$

where $\gamma$ is the threshold parameter.

Note that (4) can be also written as:

$$
\Delta x_{t}=A_{1}^{\prime} X_{t-1} z_{1 t}(\gamma)+A_{2}^{\prime} X_{t-1} z_{2 t}(\gamma)+u
$$

In (5)

$$
\begin{aligned}
& z_{1 t}(\gamma)=I\left(w_{t-1}(\beta) \leq \gamma\right) \\
& z_{2 t}(\gamma)=I\left(w_{t-1}(\beta) \succ \gamma\right)
\end{aligned}
$$

where $I($.$) is the indicator function.$

The maximum likelihood estimation (MLE) is used to estimate the threshold parameter, $\gamma$ by conducting a joint grid search over the two unknowns ( $\beta$ and $\gamma$ ). In the event that there is no cointegration between long-term and short-term rates, the model collapses to linear VECM with a time varying parameter with (4) now re-written as:

$$
\Delta x_{t}=A\left(w_{t-1}\right) X_{t-1}+u_{t} \quad \text { with } \quad A\left(w_{t-1}\right)=A_{1} z_{1 t}(\gamma)+A_{2} z_{2 t}(\gamma)
$$

Since there is no threshold, the linear model is relatively easy to estimate under the null of a null hypothesis (no threshold cointegration) since testing can carried based on the Lagrange Multiple (LM) principle. This is referred to literature as the Davies problem. ${ }^{\mathrm{x}}$ Incidentally, this is test of null hypothesis of no linear cointegration and the alternative of threshold cointegration. However, the threshold parameter $(\gamma)$ is not identified under the null hypothesis, Hansen and Seo (2002) base their inference on two tests; the $\operatorname{SupLM} M^{0}$ in cases when $\beta$ is 
known apriori (thus imposed at estimation), and $\operatorname{SupLM}$ for cases when $\beta$ is unknown and must be estimated. It is highly unlikely that a researcher would have apriori knowledge of the cointegrating vector $(\beta)$, thus we focus on the $\operatorname{SupLM}$ test for the case where $\beta$ is estimated. The threshold effect is only meaningful if $0<P\left(w_{t-1} \leq \gamma\right)<1$ otherwise (5) and (6) collapse to (7). According to Hansen and Seo (2002) the threshold constraint is set as:

$$
\pi_{0} \leq P\left(w_{t-1} \leq \gamma \leq 1-\pi_{0}\right.
$$

where $\pi_{0}$ is the trimming parameter, set to equal to 0.05 and $1-\pi_{0}=0.95$. The estimation of (4) by MLE under the assumption that the errors $u_{t}$ are iid and Gaussian with following unconstrained a Gaussian likelihood of the form:

$$
\ell_{n}\left(A_{1}, A_{2}, \Sigma, \beta, \gamma\right)=-\frac{n}{2} \log |\Sigma|-\frac{1}{2} \sum_{t=1}^{n} u_{t}\left(A_{1}, A_{2}, \Sigma, \beta, \gamma\right)^{\prime} \Sigma^{-1} u_{t}\left(A_{1}, A_{2}, \Sigma, \beta, \gamma\right)
$$

where $u_{t}\left(A_{1}, A_{2}, \Sigma, \beta, \gamma\right)=\Delta x_{t}-A_{1}{ }^{\prime} X_{t-1}(\beta) z_{1 t}(\beta, \gamma)-A_{2}{ }^{\prime} X_{t-1}(\beta) z_{2 t}(\beta, \gamma)$

Hansen and Seo (2002) concentrate out $\left(A_{1}, A_{2}, \Sigma\right.$, ), that is, hold ( $\left.\beta, \gamma\right)$ fixed and estimate the constrained the MLE for $\left(A_{1}, A_{2}, \Sigma\right.$, ). They derive the concentrated likelihood function from (9) in addition to a modified constraint in (8). The $\operatorname{MLE}(\hat{\beta}, \hat{\gamma})$ minimizes $\log |\hat{\Sigma}(\beta, \gamma)|$ in (10) subject to the normalization on $\beta$ in (8) now re-stated as (11).

$$
\begin{aligned}
& \left.\left.\ell_{n}(\beta, \gamma)=\ell_{n}(\text { 染算 } \beta, \gamma), A_{2}(\beta, \gamma), \text { 辇 } \beta, \gamma\right), \beta, \gamma\right)=-\frac{n}{2} \log |\Sigma(\beta, \gamma)|-\frac{n p}{2} \\
& \pi_{0} \leq \frac{1}{n} \sum_{t=1}^{n} I\left(x_{t}{ }^{\prime} \beta \leq \gamma\right) \leq 1-\pi_{0}
\end{aligned}
$$

With two endogenous variables $\left(R_{t}\right.$ and $\left.r_{t}\right)$, but with (10) a non-smooth function, we resort to grid search over the $\operatorname{space}(\beta, \gamma){ }^{\mathrm{xi}}$ The idea is to use a consistent estimate of $\beta$ denoted as $\tilde{\beta}$ obtained from estimating a linear model and express an estimate of the error-correction 
term as $\quad \tilde{w}_{t-1}=w_{t-1}(\tilde{\beta})$. We then define the lower and upper bound of the threshold parameter space to be searched as $\left[\gamma_{L}, \gamma_{U}\right]$ to provide support for $\tilde{w}_{t-1}$. We also define a lower and upper bound for the cointegrating scalar $(\beta)$ from the linear estimate $\tilde{\beta}$ as $\left[\beta_{L}, \beta_{U}\right]$. The grid search over $(\beta, \gamma)$ checks all pairs of $(\gamma, \beta)$ on grids $\left[\gamma_{L}, \gamma_{U}\right]$ and $\left[\beta_{L}, \beta_{U}\right]$ subject to the constraint in (11). There is no guarantee that MLE estimates, $\hat{\beta}$ and $\hat{\gamma}$ as values of $\beta$ and $\gamma$ will yield the lowest value of $\log |\hat{\Sigma}(\beta, \gamma)|$ even in the case of two endogenous variables $\left(e_{t}, r_{t}\right)$ with one lag.

The implementation of the MLE does not come with a fully fledged distribution theory or theory of inference.xii Hansen and Seo (2002) assume that in the threshold cointegration model $(\hat{\beta}, \hat{\gamma})$ converges to $(\beta, \gamma)$ as the sample size $(n)$ increases. Given that assumption, they argue that the slope estimates of coefficient matrices $\hat{A}_{1}$ and $\hat{A}_{2}$ have normal asymptotic distributions as if $\beta$ and $\gamma$ are known and suggest that reported standard errors that are reported are useful but great caution should be given to results. In testing for a threshold, we employ LM statistics. In cases where $\tilde{\beta}$ is an estimate of $\beta$ but there is no estimate of $\gamma$ under the null hypothesis of threshold cointegration, the LM statistic is undefined but Davies (1987) proposed the following supremum test statistic.xiii

$$
\operatorname{Sup} L M=\sup \underset{\gamma_{L} \gamma \leq \gamma_{U}}{\operatorname{LM}}(\tilde{\beta}, \gamma)
$$

In this case, the search region $\left[\gamma_{L}, \gamma_{U}\right]$ is arranged such that $\gamma_{L}$ is the $\pi_{0}$ percentile of the error-correction term, $\tilde{w}_{t-1}$ and $\gamma_{U}$ is the $\left(1-\pi_{0}\right)$ percentile. This procedure implements constraint (11). ${ }^{\text {xiv }}$ Since $\operatorname{LM}(\tilde{\beta}, \gamma)$ is non-differentiable in $\gamma$ (it is discontinuous if there is a threshold value), to implement (12) requires a grid search over space $\left[\gamma_{L}, \gamma_{U}\right]$. In cases where $\beta$ (cointegrating scalar) is unknown and must be estimated, the LM statistic is discontinuous in $\beta$ due to the presence of an indicator function $I$ in (6) and it is also a function of $x_{t-1}$, a 
non-stationary variable. In addition to these concerns, $x_{t-1}$ is also part of the indicator function which limits the use of Taylor series methods to simplify the problem. Hansen and Seo (2002) suggest that asymptotic distribution theory applicable in the $S u p L M^{0}$ test is applicable in situations when $\beta$ is unknown and must be estimated ( SupLM ).

Since the asymptotic distribution of $\operatorname{SupLM} *$ (first order approximation to the asymptotic null distribution of is SupLM ) in threshold tests is unknown, it can be calculated in two ways by simulation methods as in Hansen and Seo (2002). The fixed regressor bootstrap by Hansen $(1996,2000 \mathrm{~b})$ provides $p$-values when regressors $\tilde{X}_{t-1} z_{1 t}(\tilde{\beta}, \gamma)$ and $\tilde{X}_{t-1} z_{2 t}(\tilde{\beta}, \gamma)$ are held at their sample values. The main advantage from getting $\mathrm{p}$-values this way for threshold testing is that it allows for heteroscedasticity of unknown form. The $p$ '-values are obtained by counting the percentage of simulated SupLM which exceed the actual SupLM (Hansen and Seo, 2002; p.304). There are two identifiable problems with the fixed regressor bootstrap method. First, since it only approximates the asymptotic distribution, it does not allow for an improved rate of convergence or asymptotic refinement. Second, it is difficult to include conditional heteroscedasticity without specifying a data-generating mechanism - often unknown.

On the other hand, a second method, the parametric residual bootstrap approach, does require a complete specification of equation (3) in addition to assumptions about the error term $\left(u_{t}\right)$, and

a characterization of initial conditions. Following Hansen and Seo (2002), we assume that $u_{t}$ is iid from an unknown distribution, and fixed initial conditions. This method calculates the sampling distribution of the test SupLM using model (3) and parameters ( $\tilde{\beta}, \tilde{A}$ and bivariate residual estimates, $\tilde{u}_{t}$ are obtainable under the null hypothesis of no threshold cointegration.

As in the case of the fixed regressor bootstrap, the statistic SupLM* is calculated and saved. The bootstrap $p$-value is the percentage of simulated statistics which exceed the actual statistic. Since $\beta$ and $\gamma$ are both unknown, they must be estimated by MLE via a grid search method. We use the SupLM test statistic and $p$-values from the fixed regressor bootstrap and the parametric residual bootstrap to test for the significance of the parameters. The model presented in this paper yields one threshold if the adjustment parameter differs significantly between two regimes. 


\section{Estimated Results and Discussions}

The definitions of variables employed in this paper are shown in Table 1.

Table 1. Definition of Variables

\begin{tabular}{|l|l|}
\hline Original Variables & Growth Rate Variables \\
\hline Repurchase Rate/Bank Rate =RP & Growth rate of RP = RP1 \\
\hline Money market rate (NCD) =MMR & Growth rate of MMR = MR1 \\
\hline Treasury Bill Rate =TB & Growth rate of the TB =TB1 \\
\hline Deposit rate = DR & Growth rate of the DR =DR1 \\
\hline Lending Rate = LR & Growth rate of the LR=LR1 \\
\hline Government Bond Yield = GBY & Growth rate of the GBY=GBY1 \\
\hline Mortgage Lending Rate (by banks)=MLR_B & Growth rate of the MLR_B = MLRBA \\
\hline Mortgage Lending Rate (Participation Bonds)=MLR_Bond & Growth rate of the MLR_Bonds = MLRBO \\
\hline
\end{tabular}

Prior to estimation, long-term and short-term interest rates were tested for the presence of unit root using the ADF and PP tests and the results are reported in Table 2. In case of the ADF on levels, $(*)$ variables failed to reject the null of a unit root. With first differences, the ADF (**) rejects the null of that the series have a unit root. With the use of the PP for levels, all series failed to reject the null of a unit $\operatorname{root}(\mathbf{x})$ while first differences reject the null of a unit for both series $(\mathbf{z})$. We can conclude that all series are non-stationary I(1).

Table 2. Unit Root Tests, 1990M1 to 2010M7

\begin{tabular}{|c|c|c|c|c|}
\hline Variable & $\mathrm{ADF}(\mathrm{C})$ & $\mathrm{ADF}(\mathrm{C} \& \mathrm{~T})$ & PP (Level) & PP $\left(1^{\text {st }}\right.$ dif $)$ \\
\hline $\mathrm{RP}$ & -2.6705 & -3.3130 & -0.93674 & \\
\hline$\Delta \mathrm{RP}$ & $-3.4483 *$ & $-3.4217 *$ & & $-11.0321 *$ \\
\hline MMR & -2.7150 & -2.7756 & -1.5581 & \\
\hline$\Delta \mathrm{MMR}$ & $-5.3839 *$ & $-5.3684 *$ & & $-5.1695^{*}$ \\
\hline TB & -2.6600 & -2.8348 & -1.2011 & \\
\hline$\Delta \mathrm{TB}$ & $-6.4799 *$ & $-6.4632 *$ & & $-10.1152 *$ \\
\hline DR & -2.5099 & -2.4206 & -1.7475 & \\
\hline$\Delta \mathrm{DR}$ & $-7.1929 *$ & $-7.1828 *$ & & $-9.1026^{*}$ \\
\hline LR & -2.7868 & -3.3278 & -0.8086 & \\
\hline$\Delta \mathrm{LR}$ & $-3.3392 *$ & $-3.3048 *$ & & $-11.5539 *$ \\
\hline GBY & -1.9291 & -1.8799 & -1.2022 & \\
\hline$\Delta \mathrm{GBY}$ & $-9.1462 *$ & $-9.1787 *$ & & $-11.0649 *$ \\
\hline MLR_B & -2.7317 & -3.4607 & -0.7701 & \\
\hline$\triangle M L R \_B$ & $-3.6085^{*}$ & $-3.5851^{*}$ & & $-8.5058^{*}$ \\
\hline MLR_Bonds & -2.5509 & -3.0164 & -0.7731 & \\
\hline$\triangle \mathrm{MLR}$ RBonds & $-3.9953 *$ & $-3.9771 *$ & & $-11.2520 *$ \\
\hline
\end{tabular}

Critical Values for ADF (C), ADF (C \& T) unit root tests are -2.8825 and -3.4430 respectively. $\mathrm{C}$ and $\mathrm{T}$ represent a constant and time trend respectively. The critical values for the PP unit root tests are identical to the ADF values. The * indicates rejection of the unit root hypothesis. That is, both the ADF and PP unit rests reject the hypothesis that there is a unit root for all variables in first differences $(\Delta)$

All results are reported in Table 3(a) to 3(i) while interest rate response to error correction is Figures 2 to 9 . For the most part, results tend to reject the presence of linear cointegration in favor of threshold cointegration since both $p$-values for fixed regressor and residual bootstraps are close to zero. ${ }^{\mathrm{xv}}$ Note that in Table 3 money market rates, TB rate, deposit and loan rates, 
government bond yield, mortgage rates are represented by $R_{t}$ while the repo rate and for one case, the government bond yield is represented by $r_{t}$.

The parameter for the bivariate relationship between the money market rate (a 3-month certificate of deposit) and the repo rate were obtained by minimizing (10) over a $300 \times 300$ grid on the parameters $(\gamma, \beta)$. The procedure is repeated for all other interest rates. The estimated cointegrating relationship is $w_{t}=R_{t}-1.13 r_{t}$ which is greater than unity in Table 3(a). In other words, with $\beta=1.13$, then is evidence of 'overshooting' where the extent of overshooting is 0.13. The estimated threshold is $\hat{\gamma}=-1.13$. The first or usual regime happens as $R_{t} \leq 1.13 r_{t}-1.13$ and it has $95 \%$ of observations. Below $\hat{\gamma}=-1.13$, the error-correction is accomplished by money market rate and also above the threshold value. This means that when the money market rate is 1.13 points below the short rate, adjustment is via the money market rate although the error correction term $\left(\Delta w_{t-1}=-0.48\right)$ is not statistically significant in money market rate model. The same holds in the repo model in the first regime. The second regime (extreme regime) is when $R_{t}>1.13 r_{t}-1.13$ with $5 \%$ of observations. In the extreme regime, $\Delta R_{t-1}$ and $\Delta r_{t-1}$ have significant error-correction effects for $\Delta r_{t-1}$ (first regime, money market model, repo model; money market model, second regime).

Table 3(a). The Relationship between the Money Market Rate and the Repo Rate

\begin{tabular}{|c|c|c|c|c|}
\hline \multicolumn{3}{|c|}{ First Regime } & \multicolumn{2}{|c|}{ Second Regime } \\
\hline Variables & $\begin{array}{ll}\text { Money } & \text { Market } \\
\text { Model }\left(\Delta R_{t}\right) & \end{array}$ & $\begin{array}{ll}\text { Repo } & \text { Rate } \\
\operatorname{Model}\left(\Delta r p_{t}\right) & \end{array}$ & $\begin{array}{l}\text { Money Market } \\
\text { Rate Model } \\
\left(\Delta M M R_{t}\right)\end{array}$ & $\begin{array}{l}\text { Repo Rate Model } \\
\left(\Delta r p_{t}\right)\end{array}$ \\
\hline $\begin{array}{l}\text { Const } \\
\Delta w_{t-1} \\
\Delta R_{t-1} \\
\Delta r_{t-1} \\
\text { Threshold } \\
\text { parameter, } \gamma \\
\text { Cointegration } \\
\text { Vector, } \beta \\
\% \text { of Obs. per } \\
\text { regime }\end{array}$ & $\begin{array}{l}-0.14(1.67) \\
-0.48(-1.45) \\
0.056(0.83) \\
0.65(3.98) \\
-1.13 \\
\\
1.13 \\
95 \%\end{array}$ & $\begin{array}{l}-0.000(-0.003) \\
0.012(0.35) \\
0.14(2.53) \\
0.26(2.34)\end{array}$ & $\begin{array}{l}0.7(0.16) \\
-0.02(0.05) \\
-1.23(-5.78) \\
1.29(5.43)\end{array}$ & $\begin{array}{l}0.00(0.00) \\
0.00(0.00) \\
0.00(0.00) \\
0.00(0.00)\end{array}$ \\
\hline
\end{tabular}




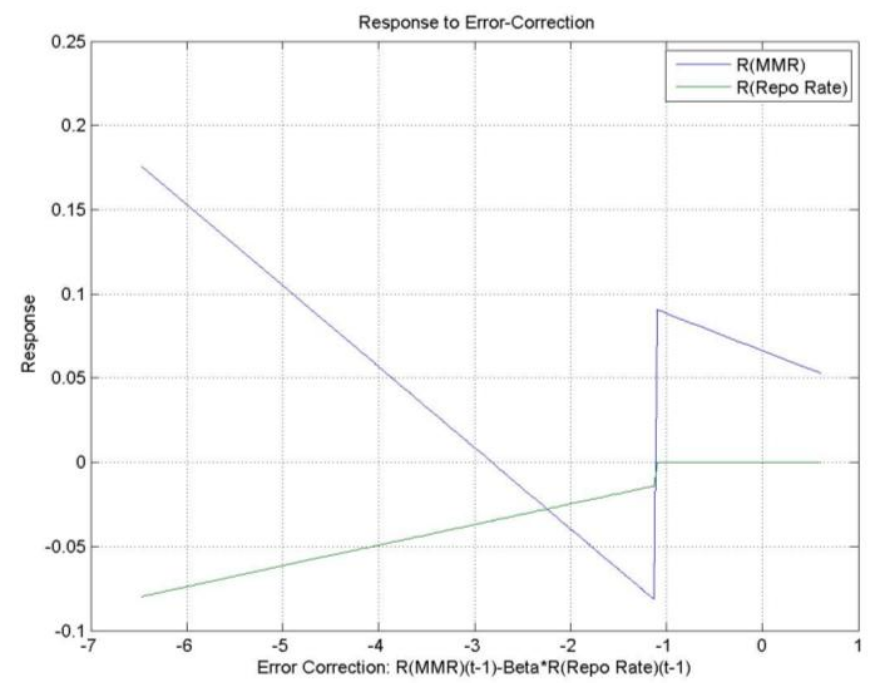

Figure 2 shows the plot of the error-correction effect for the money market and the repo rate. Figure 2. Interest Rate Response to the Error-Correction: money market and the Repo Rate For the Treasury Bill (TB) rate and the repo rate, the estimated cointegrating relationship is $w_{t}=R_{t}-0.98 r_{t}$. In other words, with $\beta=0.98$, it clear that the cointegrating vector is quite close to unity. The results are in Table 3(b). The estimated threshold is $\hat{\gamma}=0.204$. The first or usual regime happens as $R_{t} \leq 0.98 r_{t}-0.204$ and it has $94 \%$ of observations. Below $\hat{\gamma}=0.204$, the error-correction is accomplished by the TB model in the first regime. The error-correction term $\left(w_{t}=-0.11\right)$ is only significant in TB model in the first regime. The second regime (extreme regime) is when $R_{t}>0.98 r_{t}-0.204$ with $6 \%$ of observations. In both regimes, $\Delta R_{t-1}$ and $\Delta r_{t-1}$ have significant error-correction effects except for $\Delta r_{t-1}$ in the first regime in the repo model.

Table 3(b). The Relationship between the Repo Rate and the Treasury Bill Rate

\begin{tabular}{|c|c|c|c|c|}
\hline Variables & $\begin{array}{ll}\text { Treasury Bill } & \text { Rate } \\
\text { Model }\left(\Delta R_{t}\right) & \end{array}$ & $\begin{array}{l}\text { Repo Rate } \\
\text { Model }\left(\Delta r p_{t}\right)\end{array}$ & $\begin{array}{ll}\text { Treasury Bill } & \text { Rate } \\
\text { Model }\left(\Delta R_{t}\right) & \end{array}$ & $\begin{array}{l}\text { Repo Rate } \\
\text { Model }\left(\Delta r p_{t}\right)\end{array}$ \\
\hline $\begin{array}{l}\text { Const } \\
\Delta w_{t-1} \\
\Delta R_{t-1} \\
\Delta r_{t-1} \\
\text { Threshold } \\
\text { parameter, } \gamma \\
\text { Cointegration } \\
\text { Vector, } \beta \\
\% \text { of Obs. per } \\
\text { regime }\end{array}$ & $\begin{array}{l}-0.09(-2.47) \\
-0.11(-2.35) \\
0.30(2.78) \\
0.45(3.96) \\
0.20 \\
\\
0.98 \\
94 \%\end{array}$ & $\begin{array}{l}0.02(0.37) \\
0.05(0.83) \\
0.22(2.31) \\
0.211(1.50)\end{array}$ & $\begin{array}{l}0.04(0.31) \\
-0.39(-1.07) \\
-1.00(-8.18) \\
0.47(7.59)\end{array}$ & $\begin{array}{l}-0.12(-0.79) \\
0.26(0.73) \\
-0.44(-3.44) \\
-0.11(2.31)\end{array}$ \\
\hline
\end{tabular}




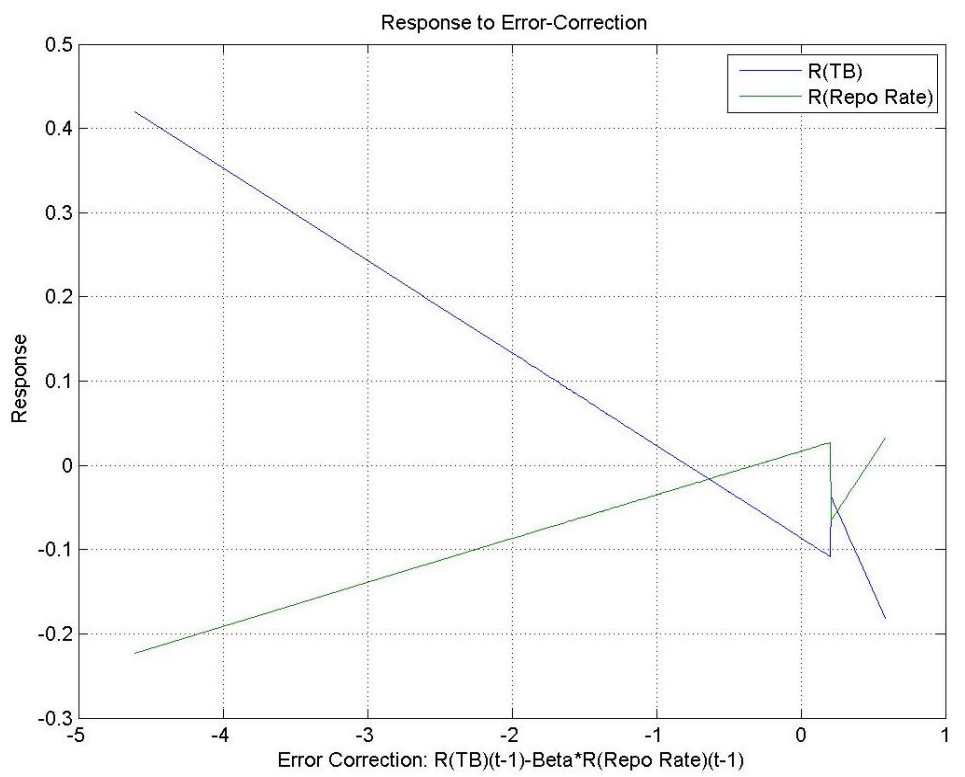

Figure 3. Interest Rate Response to the error-correction: TB rate and the Repo Rate

Figure 3 shows the plot of the error-correction effect for the TB rate and the repo rate. Below $\hat{\gamma}=0.204$, the TB model shows significant negative $\left(\Delta w_{t-1}=-0.11\right)$ error-correction while in the second regime above the threshold, error-correction terms have the correct sign but are statistically insignificant.

Table 3(c). The Relationship between the Repo Rate and the Deposit Rate

\begin{tabular}{|c|c|c|c|c|}
\hline Variables & $\begin{array}{ll}\text { Deposit } & \text { Rate } \\
\text { Model }\left(\Delta R_{t}\right) & \\
\end{array}$ & $\begin{array}{ll}\text { Repo } & \text { Rate } \\
\text { Model }\left(\Delta r p_{t}\right) & \\
\end{array}$ & $\begin{array}{ll}\text { Deposit } & \text { Rate } \\
\text { Model }\left(\Delta R_{t}\right) & \\
\end{array}$ & $\begin{array}{ll}\text { Repo } & \text { Rate } \\
\operatorname{Model}\left(\Delta r p_{t}\right) & \\
\end{array}$ \\
\hline $\begin{array}{l}\text { Const } \\
\Delta w_{t-1} \\
\Delta R_{t-1} \\
\Delta r_{t-1} \\
\text { Threshold } \\
\text { parameter, } \gamma \\
\text { Cointegration } \\
\text { Vector, } \beta \\
\% \text { of Obs. per } \\
\text { regime }\end{array}$ & $\begin{array}{l}1.93(1.45) \\
1.24(1.34) \\
0.27(0.82) \\
1.43(4.40) \\
-0.98 \\
0.88 \\
5 \%\end{array}$ & $\begin{array}{l}-1.27(-3.20) \\
-0.90(-3.20) \\
0.41(2.20) \\
0.35(3.15)\end{array}$ & $\begin{array}{l}-0.04(-1.31) \\
-0.05(2.04) \\
0.04(0.23) \\
0.33(2.64) \\
\\
95 \%\end{array}$ & $\begin{array}{l}-0.04(-1.12) \\
0.10(0.81) \\
0.27(2.32) \\
0.01(0.10)\end{array}$ \\
\hline
\end{tabular}

Table 3(c) shows results from the relationship between the repo and the deposit rates. The estimated cointegrating relationship is $w_{t}=R_{t}-0.88 r_{t}$ which is greater than unity in Table 3(c).

In other words, with $\beta=0.88$, then is evidence of 'overshooting' where the extent of overshooting is 0.13 . The estimated threshold is $\hat{\gamma}=-0.98$. The first or usual regime happens as $R_{t} \leq 0.88 r_{t}-0.98$ and it has $95 \%$ of observations. Below $\hat{\gamma}=-0.98$, the error-correction is accomplished by deposit rate model and also above the threshold value. The error correction 


\section{Al Macrothink}

Business and Economic Research

ISSN 2162-4860

2013, Vol. 3, No. 1

term is statistically significant in repo rate model (extreme regime) with 5\% observations, and the deposit rate model (deposit model, second regime). The second regime (usual regime) is when $R_{t}>0.88 r_{t}-0.98$ with $95 \%$ of observations. In the extreme regime, $\Delta R_{t-1}$ and $\Delta r_{t-1}$ have significant error-correction effects for $\Delta r_{t-1}$ (first regime, deposit model and repo model; deposit rate model, second regime). Figure 4 shows the plot of the error-correction effect for the deposit rate and the repo rate.

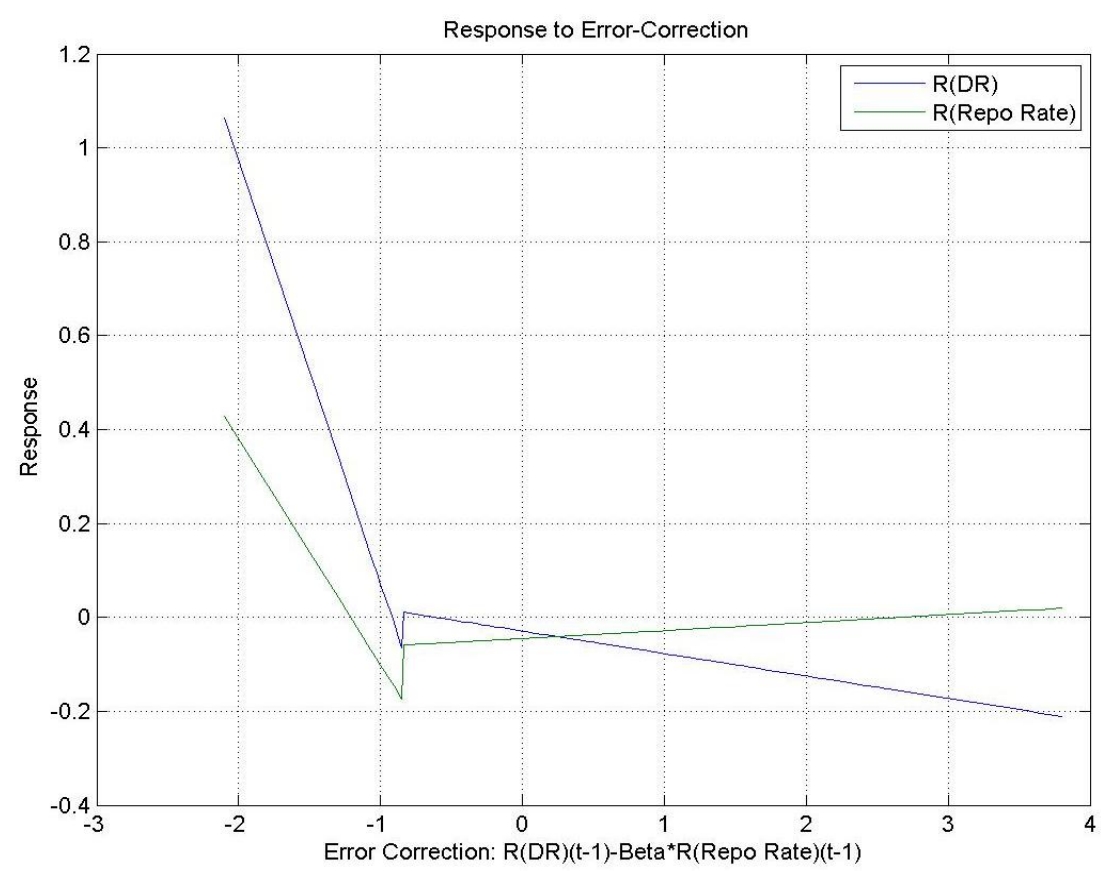

Figure 4. Interest Rate Response to the error-correction: DR rate and the Repo Rate

The estimated cointegrating relationship between the 10-year government bond yield and the repo rate is $w_{t}=R_{t}-1 r_{t}$ which equals unity in Table 3(d). In other words, with $\beta=1.00$ and the estimated threshold is $\hat{\gamma}=-2.84$. The first or extreme regime happens as $R_{t} \leq 1 r_{t}-2.84$ and it has $8 \%$ of observations. Below $\hat{\gamma}=-2.84$, the error-correction is accomplished by adjustment of the government bond yield and very little error-correction effects above the threshold value. The second regime (usual regime) is when $R_{t}>1 r_{t}-2.84$ with $92 \%$ of observations. In the extreme regime, $\Delta R_{t-1}$ and $\Delta r_{t-1}$ have insignificant error-correction effects for except for $\Delta R_{t-1}$ (first regime, repo model; government bond yield, second regime).

Table 3(d). The Relationship between the Repo Rate and the Government Bond Yield

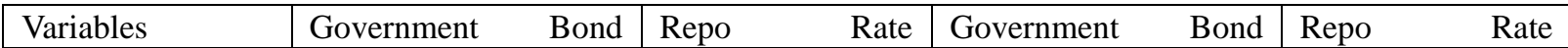




\begin{tabular}{|l|l|l|l|l|}
\hline & Yield Model $\left(\Delta R_{t}\right)$ & Model $\left(\Delta r p_{t}\right)$ & Yield Model $\left(\Delta R_{t}\right)$ & $\operatorname{Model}\left(\Delta r p_{t}\right)$ \\
\hline Const & $-2.29(-2.82)$ & $-0.55(-1.13)$ & $-0.02(-0.90)$ & $-0.03(-0.90)$ \\
$\Delta w_{t-1}$ & $-0.59(-2.81)$ & $-0.06(-0.47)$ & $-0.02(-1.10)$ & $0.024(1.36)$ \\
$\Delta R_{t-1}$ & $-0.17(0.82)$ & $-0.27(-2.14)$ & $0.31(4.27)$ & $0.087(1.01)$ \\
$\Delta r_{t-1}$ & $1.43(-0.47)$ & $0.82(9.13)$ & $-0.04(0.94)$ & \\
Threshold & & & & \\
parameter, $\gamma$ \\
$\begin{array}{l}\text { Cointegration } \\
\text { Vector, } \beta \\
\text { of Obs. per } \\
\text { regime }\end{array}$ & -2.84 & & & \\
\hline
\end{tabular}

Figure 5 shows the plot of the error-correction effect for the government bond yield and the repo rate.

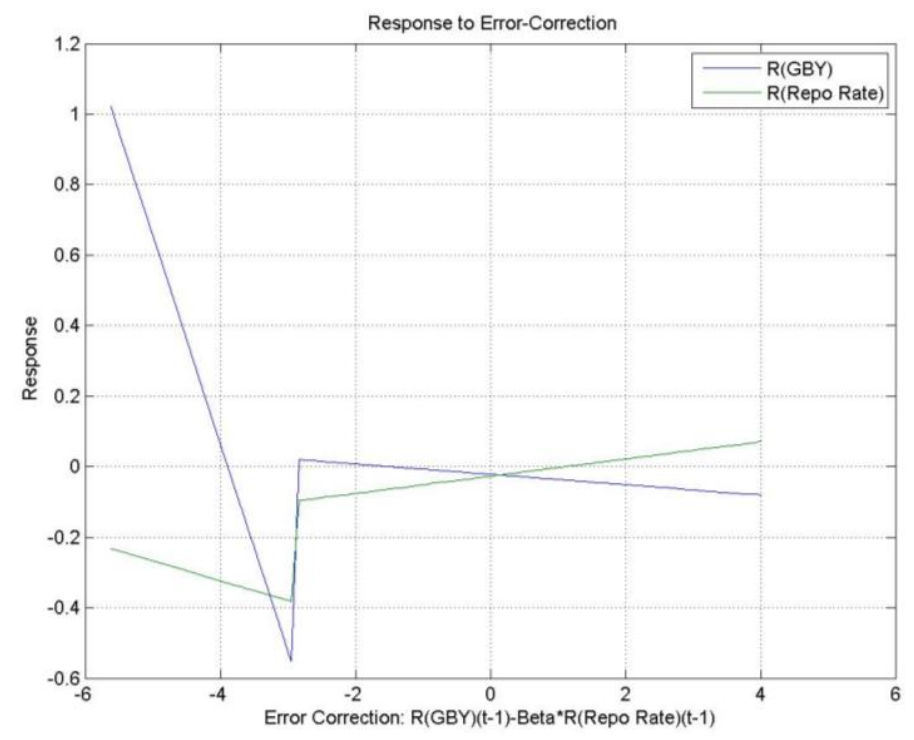

Figure 5. Interest Rate Response to the error-correction: 10-year government bond rate and the Repo Rate

The estimated cointegrating relationship between the loan rate and the repo rate is $w_{t}=R_{t}-0.96 r_{t}$ which equals unity in Table 3(e). In other words, with $\beta=0.96$ and the estimated threshold is $\hat{\gamma}=-3.74$. The first or extreme regime happens as $R_{t} \leq 0.96 r_{t}-3.74$ and it has $11 \%$ of observations. Below $\hat{\gamma}=-3.74$, the error-correction is accomplished by adjustment in the repo rate and very little error-correction effects above the threshold value. The second regime (usual regime) is when $R_{t}>0.96 r_{t}-3.74$ with $89 \%$ of observations. In the extreme regime, $\Delta R_{t-1}$ and $\Delta r_{t-1}$ have significant error-correction effects in the loan rate model only. 
Table 3(e). The Relationship between the Repo Rate and the Loan Rate

\begin{tabular}{|l|l|l|l|l|}
\hline Variables & $\begin{array}{l}\text { Loan Rate Model } \\
\left(\Delta R_{t}\right)\end{array}$ & $\begin{array}{l}\text { Repo Rate } \\
\text { Model }\left(\Delta r p_{t}\right)\end{array}$ & $\begin{array}{l}\text { Loan Rate Model } \\
\left(\Delta R_{t}\right)\end{array}$ & $\begin{array}{l}\text { Repo Rate } \\
\text { Model }\left(\Delta r p_{t}\right)\end{array}$ \\
\hline Const & $-0.14(-0.16)$ & $1.81(1.63)$ & $2.39(5.11)$ & $0.82(1.74)$ \\
$\Delta w_{t-1}$ & $0.40(0.15)$ & $-0.62(-1.90)$ & $-0.62(-5.17)$ & $-0.22(-1.81)$ \\
$\Delta R_{t-1}$ & $-0.24(-3.27)$ & $0.53(1.31)$ & $0.05(0.65)$ & $0.20(2.09)$ \\
$\Delta r_{t-1}$ & $1.26(5.67)$ & $0.29(1.21)$ & $0.22(2.36)$ & $-0.02(-0.17)$ \\
$\begin{array}{l}\text { Threshold parameter, } \\
\gamma\end{array}$ & -3.74 & & & \\
$\begin{array}{l}\text { Cointegration Vector, } \\
\beta\end{array}$ & 0.96 & & & \\
$\%$ of Obs. per regime & & & & \\
& $11 \%$ & & $89 \%$ & \\
\hline
\end{tabular}

Figure 6 shows the plot of the error-correction effect for the loan rate and the repo rate.

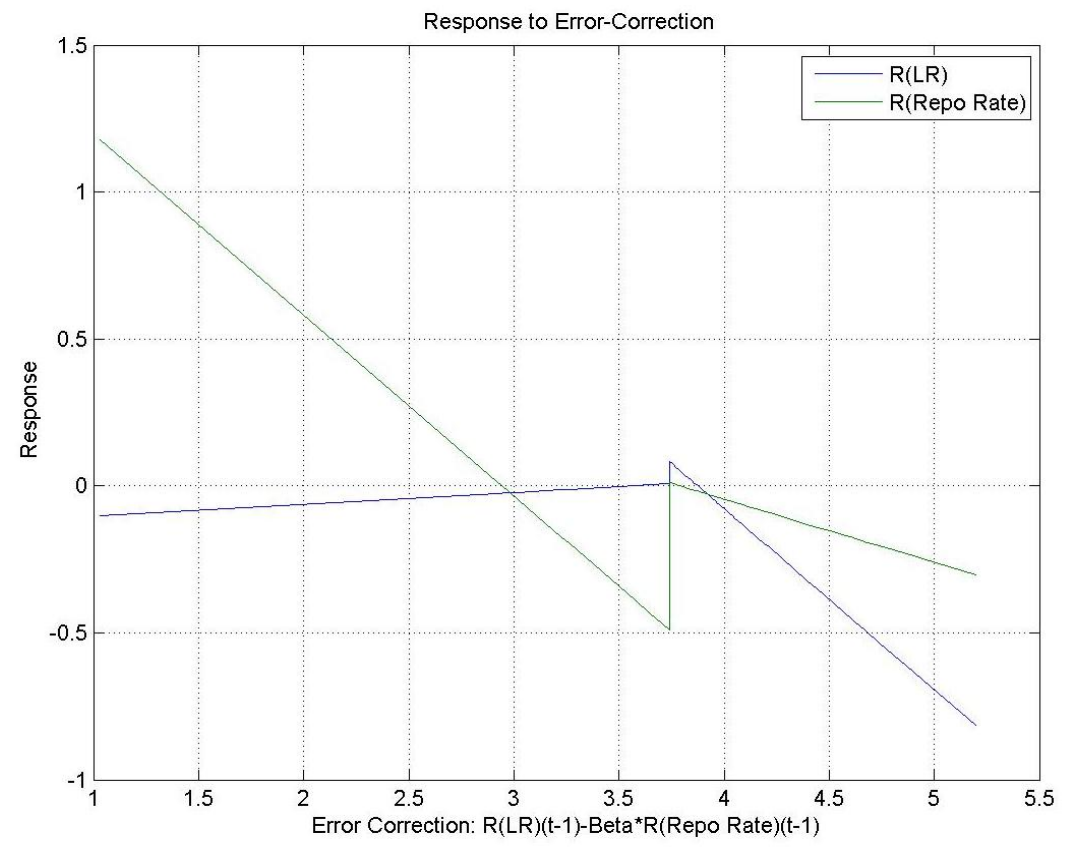

Figure 6. Interest Rate Response to the error-correction: Loan (LR) rate and the Repo Rate The estimated cointegrating relationship between the bank mortgage rate (MLR_B) and the repo rate is $w_{t}=R_{t}-0.93 r_{t}$ which equals unity in Table 3(f). In other words, with $\beta=0.93$ and the estimated threshold is $\hat{\gamma}=-3.31$. The first or extreme regime happens as $R_{t} \leq 0.93 r_{t}-3.31$ and it has $6 \%$ of observations. Below $\hat{\gamma}=-3.31$, the error-correction is accomplished by adjustment in the repo rate and very little error-correction effects above the threshold value. The error-correction term is only significant in the second regime (usual regime). The second regime (usual regime) is when $R_{t}>0.96 r_{t}-3.74$ with $89 \%$ of observations. In the extreme regime, $\Delta R_{t-1}$ and $\Delta r_{t-1}$ have some significant error-correction effects in the bank mortgage 
rate model only.

Table 3(f). The Relationship between the Repo Rate and the MLR_bank (mortgage rate)

\begin{tabular}{|c|c|c|c|c|}
\hline Variables & $\begin{array}{ll}\text { Mortgage } & \text { rate } \\
\text { Model }\left(\Delta R_{t}\right) & \\
\end{array}$ & $\begin{array}{ll}\text { Repo } & \text { Rate } \\
\text { Model }\left(\Delta r p_{t}\right) & \end{array}$ & $\begin{array}{ll}\text { Mortgage } & \text { rate } \\
\text { Model }\left(\Delta R_{t}\right) & \end{array}$ & $\begin{array}{ll}\text { Repo } & \text { Rate } \\
\operatorname{Model}\left(\Delta r p_{t}\right) & \\
\end{array}$ \\
\hline Const & $0.91(1.23)$ & $-0.33(-0.62)$ & $1.37(3.79)$ & $0.23(0.52)$ \\
\hline$\Delta w_{t-1}$ & $-0.14(-0.74)$ & $-0.11(-1.03)$ & $-0.35(-3.88)$ & $-0.06(-0.59)$ \\
\hline$\Delta R_{t-1}$ & $0.56(3.29)$ & $-0.06(-0.33)$ & $-0.03(-0.40)$ & $0.03(0.27)$ \\
\hline$\Delta r_{t-1}$ & $0.15(0.41)$ & $0.77(3.87)$ & $0.33(4.45)$ & $0.17(1.43)$ \\
\hline Threshold & & & & \\
\hline parameter, $\gamma$ & 3.31 & & & \\
\hline Cointegration & & & & \\
\hline Vector, $\beta$ & 0.93 & & & \\
\hline $\begin{array}{l}\% \text { of Obs. per } \\
\text { regime }\end{array}$ & $6 \%$ & & $94 \%$ & \\
\hline
\end{tabular}

Figure 7 shows the plot of the error-correction effect for the bank mortgage rate and the repo rate.

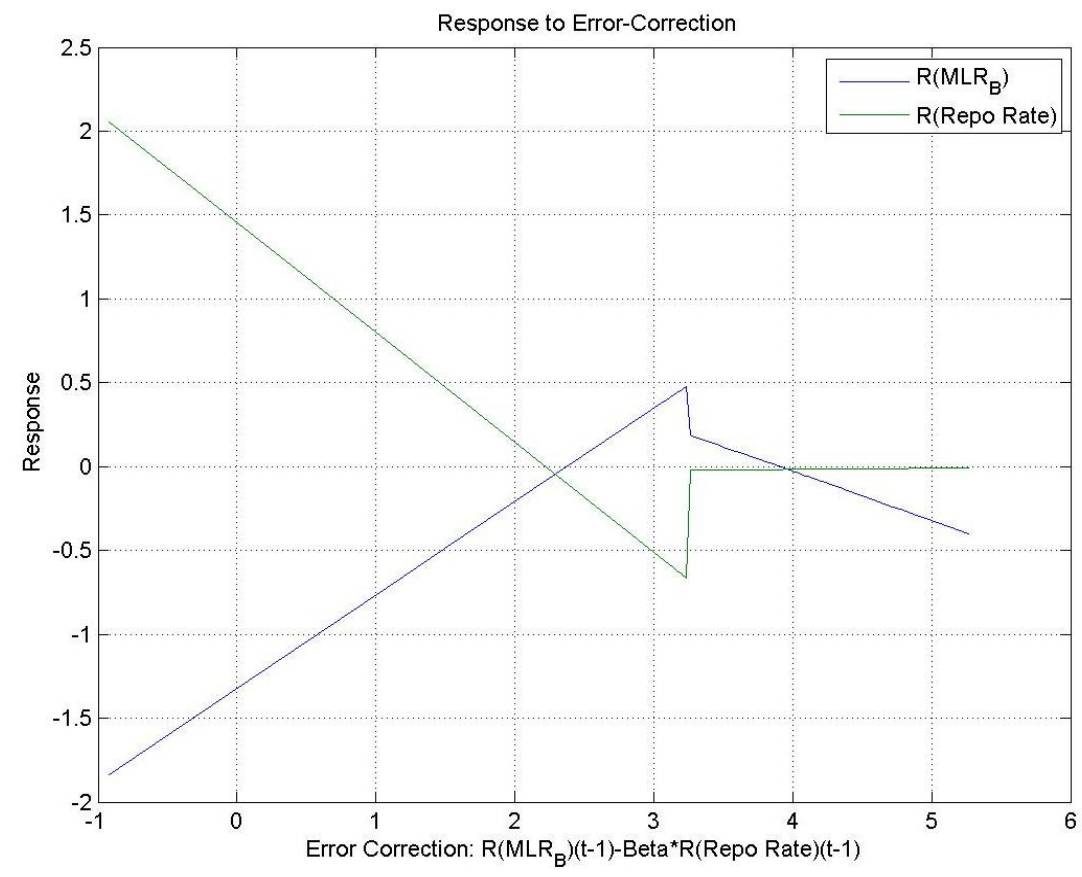

Figure 7. Interest Response to the error-correction: Bank Mortgage Rate and the Repo Rate The estimated cointegrating relationship between the bank mortgage rate (MLR_B) and the 10 -year government bond yield is $w_{t}=R_{t}-0.95 r_{t}$ which almost equals unity in Table $3(\mathrm{~g})$. In other words, with $\beta=0.95$ and the estimated threshold is $\hat{\gamma}=6.61$. The first or usual regime is $R_{t} \leq 0.95 r_{t}-6.61$ and it has $91 \%$ of observations. Below $\hat{\gamma}=6.61$, the error-correction is accomplished by adjustment in the government bond rate and very little error-correction effects above the threshold value. The error-correction term is only significant in the mortgage model 


\section{Al Macrothink}

Business and Economic Research ISSN 2162-4860 2013, Vol. 3, No. 1

in the first regime (usual regime). The second regime (extreme regime) is when $R_{t}>0.95 r_{t}-6.61$ with $9 \%$ of observations. In the usual regime, $\Delta R_{t-1}$ and $\Delta r_{t-1}$ have some significant error-correction effects in the bank mortgage rate model only.

Table 3(g). The Relationship between the Government Bond Yield and the MLR_bank (mortgage rate)

\begin{tabular}{|c|c|c|c|c|}
\hline Variables & $\begin{array}{l}\text { Mortgage rate } \\
\text { Model }\left(\Delta R_{t}\right)\end{array}$ & $\begin{array}{l}\text { Government } \quad \text { Bond } \\
\text { Yield Model }\left(\Delta g b y_{t}\right)\end{array}$ & $\begin{array}{l}\text { Mortgage rate } \\
\text { Model }\left(\Delta R_{t}\right)\end{array}$ & $\begin{array}{l}\text { Government } \quad \text { Bond } \\
\text { Yield Model }\left(\Delta g b y_{t}\right)\end{array}$ \\
\hline Const & $0.08(1.20)$ & $-0.11(-1.94)$ & $1.55(0.97)$ & $0.11(0.63)$ \\
\hline$\Delta w_{t-1}$ & $-0.02(-1.22)$ & $0.03(1.94)$ & $-0.26(-1.16)$ & $-0.06(-0.81)$ \\
\hline$\Delta R_{t-1}$ & $0.29(3.15)$ & $-0.01(-0.20)$ & $0.17(1.30)$ & $-0.41(-2.53)$ \\
\hline$\Delta r_{t-1}$ & $0.29(2.82)$ & $0.42(5.26)$ & $-0.03(-0.22)$ & $0.03(0.20)$ \\
\hline $\begin{array}{l}\text { Threshold } \\
\text { parameter, } \gamma\end{array}$ & 6.61 & & & \\
\hline Cointegration & & & & \\
\hline Vector, $\beta$ & 0.95 & & & \\
\hline regime & & & $9 \%$ & \\
\hline
\end{tabular}

Figure 8 shows the plot of the error-correction effect for the bank mortgage rate and the 10-year government bond yield.

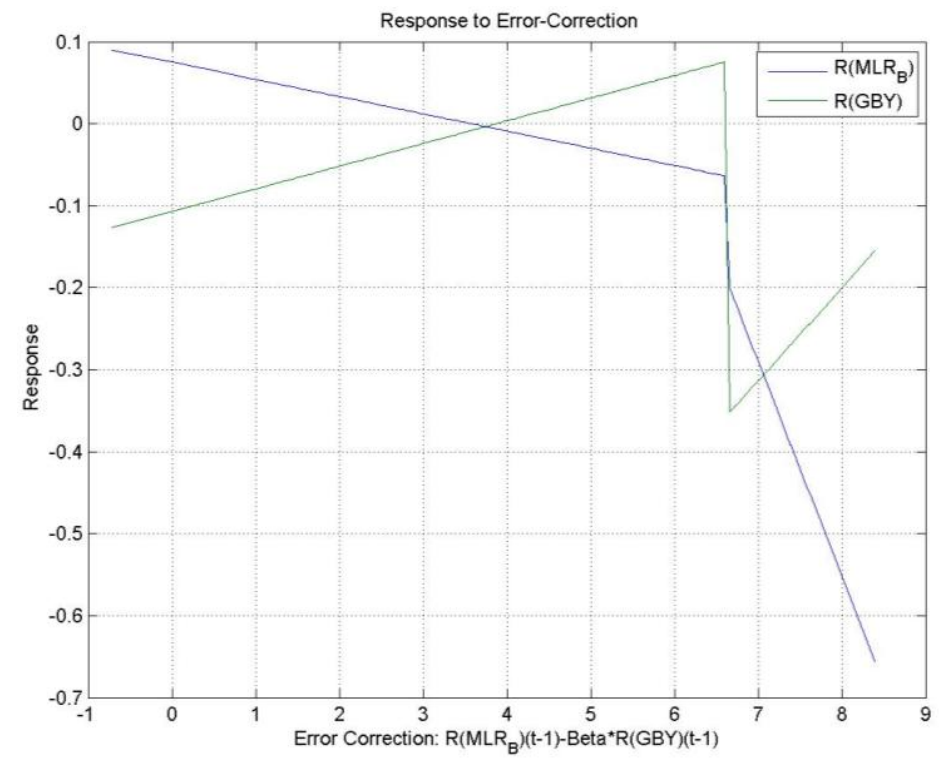

Figure 8. Interest Rate Response to the error-correction: Bank Mortgage (MLR_B) rate and the 10-year government bond yield

The estimated cointegrating relationship the participation mortgage rate (MLR_Bonds) and the 10-year government bond yield is $w_{t}=R_{t}-1.00 r_{t}$ which unity in Table 3(h) is. In other words, with $\beta=1.00$ and the estimated threshold is $\hat{\gamma}=1.06$. The first or extreme regime is $R_{t} \leq 1.00 r_{t}-1.06$ and it has $22 \%$ of observations. Below $\hat{\gamma}=1.06$, there is very little 
error-correction effects below or above the threshold value. In other words, with $\beta=1.00$, error-correction is the interest rate spread between participation rates and the 10-year government bond rate. The error-correction term is not significant in both first and second regimes. The second regime (usual regime) is when $R_{t}>1.00 r_{t}-1.06$ with $78 \%$ of observations. The diagram is similar to Figure 8.

Table 3(h). The Relationship between the Government Bond Yield and the MLR_Bonds (Participation Rates or Bonds for mortgages)

\begin{tabular}{|c|c|c|c|c|}
\hline Variables & $\begin{array}{l}\text { Participation Bonds } \\
\text { Model }\left(\Delta R_{t}\right)\end{array}$ & $\begin{array}{lr}\text { Government } & \text { Bond } \\
\text { Yield } & \text { Model } \\
\left(\Delta g b y_{+}\right) & \\
\end{array}$ & $\begin{array}{l}\text { Participation Bonds } \\
\text { Model }\left(\Delta R_{t}\right)\end{array}$ & $\begin{array}{lr}\text { Government } & \text { Bond } \\
\text { Yield } & \text { Model } \\
\left(\Delta g b y_{+}\right) & \\
\end{array}$ \\
\hline $\begin{array}{l}\text { Const } \\
\Delta w_{t-1} \\
\Delta R_{t-1} \\
\Delta r_{t-1} \\
\text { Threshold } \\
\text { parameter, } \gamma \\
\text { Cointegration } \\
\text { Vector, } \beta \\
\% \text { of Obs. per } \\
\text { regime }\end{array}$ & $\begin{array}{l}0.12(1.64) \\
0.04(0.42) \\
0.27(1.20) \\
0.61(2.07) \\
1.06 \\
1.00 \\
22 \%\end{array}$ & $\begin{array}{l}-0.06(-2.31) \\
-0.02(-0.36) \\
0.09(0.93) \\
0.67(4.48)\end{array}$ & $\begin{array}{l}-0.01(-0.09) \\
-0.03(-1.76) \\
0.25(3.31) \\
-0.19(-1.71) \\
\\
78 \%\end{array}$ & $\begin{array}{l}-0.06(-1.05) \\
0.01(0.79) \\
-0.24(-2.42) \\
0.23(2.60)\end{array}$ \\
\hline
\end{tabular}

The estimated cointegrating relationship the participation mortgage rate (MLR_Bonds) and the repo rate is $w_{t}=R_{t}-0.96 r_{t}$ which is unity in Table 3(i). In other words, with $\beta=0.96$ and the estimated threshold is $\hat{\gamma}=2.23$. The first or extreme regime is $R_{t} \leq 0.96 r_{t}-2.23$ and it has $8 \%$ of observations. Below $\hat{\gamma}=2.23$, there is very little error-correction effects below or above the threshold value. In other words, with $\beta=0.96$, error-correction is the interest rate spread between participation rates and the 10 -year government bond rate. The error-correction term is not significant in both first and second regimes. The second regime (usual regime) is when $R_{t}>0.96 r_{t}-2.23$ with $92 \%$ of observations.

Table 3(i). The Relationship between the Repo rate and the MLR_Bonds (Participation Rates or Bonds for mortgages)

\begin{tabular}{|c|c|c|c|c|}
\hline Variables & $\begin{array}{ll}\text { Participation } & \text { Bonds } \\
\text { Model }\left(\Delta R_{t}\right)\end{array}$ & $\begin{array}{l}\text { Repo Rate } \\
\text { Model }\left(\Delta r p_{t}\right)\end{array}$ & $\begin{array}{ll}\text { Participation } & \text { Bonds } \\
\text { Model }\left(\Delta R_{t}\right) & \end{array}$ & $\begin{array}{l}\text { Repo Rate } \\
\text { Model }\left(\Delta r p_{t}\right)\end{array}$ \\
\hline Const & $1.29(5.26)$ & $-0.27(-3.14)$ & $0.84(4.67)$ & $0.01(0.03)$ \\
\hline$\Delta w_{t-1}$ & $-0.16(-1.26)$ & $0.01(0.40)$ & $-0.29(-4.73)$ & $-0.01(-0.16)$ \\
\hline$\Delta R_{t-1}$ & $-0.11(-0.39)$ & $-0.22(-3.24)$ & $0.16(3.06)$ & $0.26(3.52)$ \\
\hline$\Delta r_{t-1}$ & $-0.75(-4.51)$ & $0.58(4.62)$ & $0.08(0.96)$ & $0.11(1.25)$ \\
\hline $\begin{array}{l}\text { Threshold } \\
\text { parameter, } \gamma\end{array}$ & 2.23 & & & \\
\hline $\begin{array}{l}\text { Cointegration } \\
\text { Vector, } \beta\end{array}$ & 0.96 & & & \\
\hline $\begin{array}{l}\% \text { of Obs. per } \\
\text { regime }\end{array}$ & $8 \%$ & & $92 \%$ & \\
\hline
\end{tabular}




\section{Ml Macrothink}

Figure 9 shows the plot of the error-correction effect for the participation mortgage rate and the repo rate.

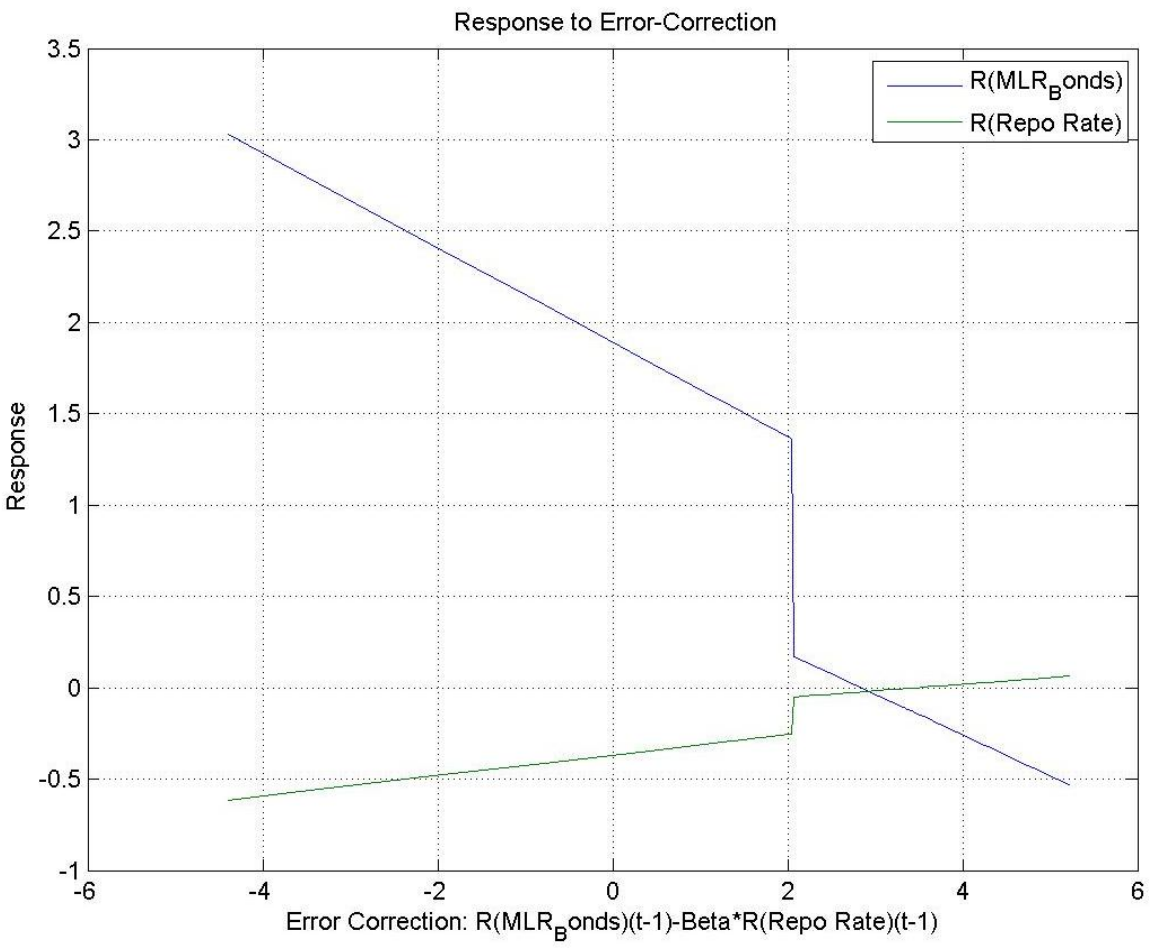

Figure 9. Interest Rate Response to the error-correction: Participation Bond rate (MLR_Bonds) and the repo rate

\section{Conclusion}

Caner and Hansen (2001) considered TAR models as alternative to linear near unit root models. These linear models assume a stationary threshold variable, which in practice is typically the lagged difference of the series.

The paper used the threshold cointegration technique to examine the relationship between long-term and short-term rates for eight yields. We employ a non-linear threshold autoregressive model that allows for heteroscedasticity in the error process. The results significantly reject the null of linear cointegration for all interest rates, paving the way to test for threshold cointegration. The alternative hypothesis - threshold cointegration means the existence of a non-linear long-run dynamic relationship between long-term and short-term rates. For the most part, error-correction effects indicate that short-term rates adjust more than long-term rates (Calvo and Reinhart, 2001). For such cases, this lends credence to the idea that minimizing the volatility of the long-term rates is more important than short-term rates. The threshold value ranges from -3.74 to 6.61 while the cointegration vector values range from 0.88 to 1.13 . Thus, the apparent near unit root behavior of many financial and economic time series may be due to omitted non-linearity that is captured with threshold cointegration.

\section{References}

Ahmad, A. H., \& Pentecost, E. J. (2005). Exchange Rates and Long-term rates: A Threshold 
Cointegration Analysis. Working Paper, Loughborough University, Leicestershire: U.K.

Andrews, D. W. K. (1993). Tests for parameter instability and structural change with unknown change point. Econometrica, 61, 821-856. http://dx.doi.org/10.2307/2951764

Andrews, D. W. K., \& Plobeberger, W. (1994). Optimal Tests when a Nuisance Parameter is Present only under the alternative. Econometrica, 62, 1383-1414. http://dx.doi.org/10.2307/2951753

Ang, A., M. Piazzesi, \& Wei M. (2006). What does the yield curve tell us about GDP growth? Journal of Econometrics, 131, 359-403. http://dx.doi.org/10.1016/j.jeconom.2005.01.032

Arize, A. C., Malindretos, J., \& Obi, Z. K. (2002). Long and Short-Term Interest Rates in 19 Countries: Test of Cointegration and Parameter Instability. Atlantic Economic Journal, 30(2), 105-120. http://dx.doi.org/10.1007/BF02299156

Aron, J., \& Muellbauer, M. (2007). Transparency, Credibility and Predictability of Monetary Policy under Inflation Targeting in South Africa. Working Paper, Nuffield College, Oxford University.

Aziakpono, M. J., Kasyoka, M., \& Manuel, J. (2007). Adjustment of Commercial Bank's Interest Rates and the Effectiveness of Monetary Policy in South Africa. The African Finance Journal, 9(1), 1-20.

Balke, N. S., \& Fomby, T. B. (1997). Threshold Cointegration. International Economic Review, 38, 627-645. http://dx.doi.org/10.1007/BF02299156

Ballim, G., \& E. Moolman, E. (2005). Testing the potency and transparency of the South

African Reserve Bank's inflation targeting policy. Hardcover.

Bonga-Bonga, L. (2008). Monetary Policy and Long Term Interest Rate in South Africa. International Business \& Economics Research, 9(10), 43-54.

Calvo, G. A., \& Reinhart, C. M. (2002). Fear of Floating. Quarterly Journal of Economics, 117(2), 379-408. http://dx.doi.org/10.1162/003355302753650274

Campbell, J. Y., \& Shiller, R. (1991). Yield Spreads and Interest Rates: A bird's eye. Review of Economic Studies, 58, 495-514. http://dx.doi.org/10.2307/2298008

Caner, M., \& Hansen, B. E. (2001), Threshold autoregression with a unit root. Econometrica, 69, 1555-1596. http://dx.doi.org/10.1111/1468-0262.00257

Chan, K. S. (1993). Consistency and limiting distribution of the least squares estimator of a threshold autoregressive model. The Annals of Statistics, 21, 520-533. http://dx.doi.org/10.1214/aos/1176349040

Cochrane, J. H., \& Piazzesi. M. (2005). Bond Risk Premia. American Economic Review, 95, 138-160. http://dx.doi.org/10.1257/0002828053828581

Cook, T., \& Hahn, T. (1989). The Effect of Changes in the Federal Funds rate Target on Market 
Interest Rates in the 1970s. Journal of Monetary Economics, 24, 331-351. http://dx.doi.org/10.1016/0304-3932(89)90025-1

Dale, S. The Effect of Changes in Official UK Rates On Market Interest Rates since 1987 (April 1993). Bank of England Working Paper No. 10, Available at SSRN: http://ssrn.com/abstract=76605

Davies, R. B. (1987). Hypothesis testing when a nuisance parameter is present only under the alternative. Biometrika, 74, 33-43.

Hamilton, J. D., \& Kim, D. H. (2002). A Re-examination of the predictability of the yield spread for real economic activity. Journal of Money, Credit and Banking, 34, 340-360. http://dx.doi.org/10.1353/mcb.2002.0040

Hansen, B. E. (1996). Inference when a nuisance parameter is not identified under the null hypothesis. Econometrica, 64, 413-430. http://dx.doi.org/10.2307/2171789

Hansen, B. E. (2000a). Sample Splitting and threshold estimation. Econometrica, 68, 575-603. http://dx.doi.org/10.1111/1468-0262.00124

Hansen, B. E. (2000b). Testing for structural change in conditional models. Journal of Econometrics, 97, 93-115. http://dx.doi.org/10.1016/S0304-4076(99)00068-8

Hansen, B. E., \& Seo, B. (2002). Testing for two-regime threshold cointegration in vector error-correction models. Journal of Econometrics, 110, 293-318. http://dx.doi.org/10.1016/S0304-4076(02)00097-0

Hardy, D. C. (1998). Anticipation and Surprises in Central Bank Interest Rate Policy. IMF Staff Papers, 45, 647-671. http://dx.doi.org/10.2307/3867588

Isakova, A. (2008). Monetary Policy Efficiency in the Economies of Central Asia. Czech Journal of Economics and Finance, 58, No. 11-12, 525-553.

Kaketsis, A., \& Sarantis, N. (2006). The Effects of Monetary Policy Changes on Market Interest Rates in Greece: An Event Study Approach. International Review of Economics and Finance, 15, 487-507. http://dx.doi.org/10.1016/j.iref.2004.09.003

Khomo, M. M., \& Aziakpono, M. J. (2007). Forecasting Recession in South Africa: a Comparison of the Yield and other Economic Indicators. South African Journal of Economics, 75(2), 194-212. http://dx.doi.org/10.1111/j.1813-6982.2007.00117.x

Mishkin, F.S. (1990). What does the term structure tell us about future inflation? Journal of Monetary Economics, 25, 77-95. http://dx.doi.org/10.1016/0304-3932(90)90046-7

Mishkin, F. S. (2004). The Economics of Money, Banking and Financial Markets and Institutions. (4 ${ }^{\text {th }}$ Edition.). New York: Pearson Addison-Wesley.

Moolman, E. (2002). The Term Structure as a Predictor of Recession. Journal for Studies in Economics and Econometrics, 26(3), 43-51.

Nel, H. (1996). The Term Structure of Interest Rates and Economic Activity in South Africa. 
The South African Journal of Economics, 64(3), 161-174.

Piazzesi, M. (2010). Affine Term Structure Models. Chapter 12. In Yacine Ait-Sahalia and Lars Hansen, Handbook of Financial Econometrics: Elsevier Edited.

Roley, V. V., \& Sellon, G. H. (1995). Monetary Policy Actions and Long-Term Interest Rates. Federal Reserve Bank of Kansas City. Economic Review, 80 (4 ${ }^{\text {th }}$ Quarter), 73-89.

Romer, C, \& Romer, D. (1989). Does Monetary Policy Matter? A new test in the Spirit of Friedman and Schwartz. NBER Macroeconomic Annual, 4, 121-170. http://dx.doi.org/10.2307/3584969

Stock, J., \& Watson, M. (2003). Forecasting output and inflation: The role of asset prices. Journal of Economic Literature, 16, 788-829. http://dx.doi.org/10.1257/002205103322436197

Taylor, J. B. (1995). The Monetary Transmission Mechanism: An Empirical Framework. Journal of Economic Perspectives, 9(4), 11-26. http://dx.doi.org/10.1257/jep.9.4.11

Thornton, D. L. (1998). Test of the Market's Reaction to Federal Funds Rate Target Changes. Federal Reserve Bank of St. Louis. Review, 27-36.

West, G. (2008). Interest Rate Derivatives in the South African Market Based on the Prime Rate. Journal of Studies in Economics and Econometrics, 32(1), 1-11.

\section{Endnotes}

'Data on 10-year government bond yields, money market rate (3-month Certificate of Deposits), and TB rate was obtained from the IMF database. Data on loan rates, deposit rates, repo rate (plus the old bank rate) was obtained directly from the South African Reserve Bank. ii Participation mortgage bonds are issued by financial institutions and offered to investors, many of whom may wish to invest relatively small amounts of money. It gives these small investors an opportunity of participating with other investors in an investment secured by a registered mortgage bond over immovable property and yielding a competitive rate of interest. Each participant who holds such a participation in a participation bond becomes a creditor of the mortgagor to the extent of the participation.

iii See West (2008).

iv The repo rate in South Africa plays a similar role to the federal funds rate in the U.S. The interest rate that the borrowing bank pays to the lending bank to borrow the funds is negotiated between two banks, and the weighting average of this rate across all such transactions is the federal funds effective rate.

${ }^{v}$ In the event that commercial banks are not able to borrow adequate funding from the repo tender, they can use the marginal lending facility. The problem with using this facility is that it increases the cost of funds for the bank since the marginal lending rate is always punitive --- well above the repo rate and the prime rate.

vi South Africa's monetary system is organized in such a manner that commercial banks get a significant portion of their short-term funding from the SARB. Prior to the Rep rate (before 
1998), the SARB used the bank rate- a rate fixed by the Reserve Bank. The adoption of the repo introduced flexibility in short-term interest rates.

vii Like exchange rate changes, the interbank rate often overshoots the equilibrium represented by the repo rate.

viii A Forward Rate Agreement (FRA) is an agreement between two parties to set future borrowing rates in advance.

${ }^{\text {ix }}$ We also imposed $\beta=1$ for all interest rates and used the $\operatorname{SupLM}{ }^{0}$ test to test for linear cointegration and threshold effects. The results are highly unsatisfactory. The results are available from us on request. Pippenger and Goering (2000) present evidence that point to the low power of linear cointegration tests in detecting threshold cointegration.

${ }^{x}$ For justification of the use of SupLM tests that avoid the Davies problem, see references cited by Hansen and Seo (2002): Davies (1987), Andrews (1993), and Andrews and Ploberger (1994).

xi We are grateful to Hansen and Seo (2002) for allowing us a free download of MATLAB codes used in this paper. The codes are available at www.ssc.wisc.edu/ bhansen.

xii Chan (1993) and Hansen (2000a, 2000b) have shown that threshold estimates have non-standard distributions and that currently, there is no relevant distribution.

xiii See Hansen (1996) for a discussion of inference when a nuisance parameter is not identified under the null hypothesis.

xiv Andrews (1993) has suggested that $\pi_{0}$ should not be too close to zero since such a

choice reduces the power of the test. The justification of (12) (referenced in Hansen and Seo (2002)) is also found in Andrews and Ploberger (1994).

${ }^{\mathrm{x} v}$ In order to select the VAR lag length for both the linear VECM and threshold VECM, we used both the AIC and BIC information criteria. The results from estimation yield cases for report $l=1$ and $l=2$ but we only report results for $l=1$. Similarly, we considered imposing the cointegrating vector, $\beta=1$ and estimating the threshold parameter $\gamma$. The results were poor and carried signs that are not supported by the term structure of interest rates literature. Finally, we estimated both the cointegrating vector and threshold parameter. These are the only results reported in the paper to conserve space. However, all other results are available from both authors.

\section{Copyright Disclaimer}

Copyright reserved by the author(s).

This article is an open-access article distributed under the terms and conditions of the Creative Commons Attribution license (http://creativecommons.org/licenses/by/3.0/). 